\title{
Seed vigor and initial growth of corn crop $^{1}$
}

\author{
Vitor Henrique Vaz Mondo ${ }^{2,3}$, Silvio Moure Cicero ${ }^{2}$, Durval Dourado-Neto ${ }^{2}$, \\ Túlio Lourenço Pupim², Marcos Altomani Neves Dias²
}

\begin{abstract}
Seed vigor is a characteristic that determines potential for fast and uniform seedling emergence and establishment of crops. Such characteristic defines crop initial growth what could have direct and indirect effects on capacity of plants in capturing natural nutritive resources and intervene in their competition intra- and interspecific. Aiming at identifying and understanding the possible effects of seed vigor on crop initial growth a field experiment was performed during two years at University of São Paulo, Piracicaba, SP, Brazil; using two seed lots at each year, which were previously characterized by tests of physiological potential as high and low vigor. Thus, five different ratios (100:0, 75:25, 50:50, 25:75, and 0:100) of seeds originating from seed lots with higher or lower vigor were used. Assessments were performed at the phenological stages of four and eight leaves by assessing plant height, stem diameter, and leaf area index. It was also observed that mean values for all variables assessed have increased according to increase of seeds with high vigor at planting row. Therefore, it is concluded that increased percentage of seeds with high vigor results in greater initial growth of cron crop until phenological stage of eight leaves.
\end{abstract}

Index terms: competitive ability, physiological potential, weed competition, Zea mays.

\section{Vigor de sementes e crescimento inicial da cultura do milho}

\begin{abstract}
RESUMO - Vigor é a característica que determina o potencial para rápida e uniforme emergência de plântulas e estabelecimento das culturas. Essa característica define crescimento inicial, o qual pode ter efeitos diretos e indiretos na capacidade da planta em capturar recursos naturais e intervir na sua competição intra e interespecífica. Objetivando identificar e entender os possíveis efeitos do vigor de sementes de milho no crescimento inicial da cultura, um experimento foi conduzido, por dois anos, na Universidade de São Paulo, Piracicaba, SP, Brasil; utilizando dois lotes de sementes a cada ano, os quais foram previamente caracterizados por testes de potencial fisiológico, como alto e baixo vigor. Assim, foram utilizados cinco diferentes proporções (100:0, 75:25, 50:50, 25:75 e 0:100) de sementes de lotes com maior ou menor vigor. As avaliações foram realizadas nos estádios fenológicos de quatro e oito folhas para altura de planta, diâmetro de colmo e índice de área foliar. Foi observado que os valores médios para todas as variáveis analisadas aumentaram de acordo com aumento de sementes com alto vigor na linha de semeadura. Assim, concluiu-se que o aumento da porcentagem de sementes com alto vigor resulta em maior crescimento inicial da cultura até o estádio fenológico de oito folhas.
\end{abstract}

Termos para indexação: habilidade competitiva, matocompetição, potencial fisiológico, Zea mays.

\section{Introduction}

Seed vigor is defined as "seed properties that determines potential for fast and uniform emergence, and development of seedlings under a wide range of field conditions" (AOSA, 2002). Generally, low germination speed, high sensibility to stresses of seeds and seedlings during germination process, and plants with slow, low and irregular growth or with less root development, are typical characteristics of seed with low physiological potential (Marcos-Filho, 2005). According to Hampton (2002),

${ }^{1}$ Submitted on 03/22/2012. Accepted for publication on 05/11/2012. ${ }^{2}$ Departamento de Produção Vegetal, USP/ESALQ, Caixa Postal 9, 13418-900 Piracicaba, SP, Brasil. seed vigor has a high influence on establishment of initial population of plants as well as on their adequate development, what will affect crop yield.

This way, low vigor seeds could diminish percentage of emerged seedlings and seedling emergence speed, initial growth, leaf area, and dry mass accumulation (Schuch et al., 2000). Differences in initial crop growth related to seed vigor are described in the literature for rice (Oryza sativa L.) (Hofs et al., 2004; Melo et al., 2006; Mielerzski et al., 2008), black oats (Avena strigosa Schreb.) (Schuch et al., 2000), corn (Zea mays L.) (Dias et al., 2010; Mondo et al., 2012a), and

${ }^{3}$ Embrapa Arroz e Feijão, GO 462, Km 12, Zona Rural, 75375-000 - Santo Antônio de Goiás, GO, Brasil.

*Corresponding author <vitor.mondo@embrapa.br> 
soybean [Glycine max (L). Merrill] (Vanzolini and Carvalho, 2002; Kolchinski et al., 2005; Kolchinski et al., 2006; Schuch et al., 2009; Dias et al., 2011).

Heterogeneities, at moment of seedlings emergence affect canopy development of plant (Pommel et al., 2002). Egli and Rucker (2012) have confirmed that high-vigor corn seeds always have more uniform emergence than low-vigor seeds. In such case, plants with a delay of emergence, at any stage will have a lower development than plants with early emergence. Within this context, the differences on competitive ability for light and other resources as water and nutrients of soil, which occur in consequence of uneven initial plant growth, will be shown.

From another view point, the competition between corn plants and weeds is a challenge to crop production; and excluding the environmental variables, it is the main cause for the yield losses in corn (Rajcan and Swanton, 2001). Furthermore, the development of an integrated weed management system, aiming at their controlling, requires studies identifying the possibilities of improving the crop interference on weed development; and the use of high vigor seeds could be one of them.

In face of the foregoing, this study was aimed at identifying and understanding the effects of seed vigor on initial growth of corn crop.

\section{Material and Methods}

\section{Experimental Design and Treatments}

A two-year field experiment was carried out during two growing seasons (2006/2007 and 2007/2008) in Piracicaba, SP, Brazil (22 $42^{\prime}$ S; $47^{\circ} 38^{\prime} \mathrm{W}$; and $546 \mathrm{~m}$ altitude) on a Rhodic Kandiudalf soil, with 24 g.dm ${ }^{-3}$ organic matter and pH 4.9. Soybean was the previous crop in both the years. Experiments were fertilized with 32, 112, and $64 \mathrm{~kg} \cdot \mathrm{ha}^{-1}$ of $\mathrm{N}, \mathrm{P}_{2} \mathrm{O}_{5}$, and $\mathrm{K}_{2} \mathrm{O}$ at planting; and $90 \mathrm{~kg} \cdot \mathrm{ha}^{-1}$ of $\mathrm{N}$, at stage of five leaves, respectively. The total rainfall and the mean temperature until the stage of eight leaves were $227.6 \mathrm{~mm}$ and $24.1^{\circ} \mathrm{C}$, for the $2006 / 2007$ growing season, and $250.9 \mathrm{~mm}$ and $24.0^{\circ} \mathrm{C}$, for the $2007 / 2008$ growing season, respectively. The treatments were arranged within a randomized complete block experimental design, with four replications. Each plot had three rows, with $0.70 \mathrm{~m}$ spacing between them; and $11 \mathrm{~m}$ long; and only using $10 \mathrm{~m}$ of central row as assessment area.

For each crop season, one corn seed lot of Hybrid DOW 8480 was used, which was provided by Dow AgroSciences, Cravinhos, SP, Brazil. Each seed lot was split in two samples: one was stored under controlled conditions of temperature and relative humidity $\left(10{ }^{\circ} \mathrm{C} ; 40 \% \mathrm{RH}\right)$ during three months; and the other was left under non-controlled environmental conditions; this manner was constituted two seed lots equals physically; but with different physiological potential, in terms of seed vigor. These seed lots were previously characterized by the physiological tests of: germination; accelerated aging; cold test; seedling emergence and emergence speed index as having high vigor (lot 1) and low vigor (lot 2) (Table 1).]

For constitution of the treatments, seeds were sown in five different ratios of vigor: high $(\mathrm{H})$ and low $(\mathrm{L})$ [100:0 (1H:0L); 75:25 (3H:1L); 50:50 (1H:1L); 25:75 (1H:3L); and 0:00 $(0 \mathrm{H}: 100 \mathrm{~L})]$, respectively, in the planting row. Each position of high vigor seed in the planting row was labeled for subsequent assessment. The plots were sown manually with three seeds per high vigor seed position and four seeds per low vigor seed position; and then thinned, keeping only one seedling per position. In such position of seeds with high vigor, only first emerging seedlings were kept, and for seedlings with low vigor, only the last emerging seedlings were kept; for achieving an uniform population of 71,429 plants.ha ${ }^{-1}$ at the two leaves stage. Plots were kept free of weeds, pests, and diseases.

Table 1. Physiological potential of corn seeds (hybrid Dow 8480) from two different lots, obtained at harvest performed in two different years (2007 and 2008); and assessed by tests of: germination (G); accelerated aging (AA); cold test (CT); electrical conductivity (EC); seedling emergence (SE); and emergence speed index (ESI).

\begin{tabular}{|c|c|c|c|c|c|c|}
\hline \multirow{2}{*}{ Test } & \multicolumn{3}{|c|}{$2006 / 2007$} & \multicolumn{3}{|c|}{$2007 / 2008$} \\
\hline & Lot 1 & Lot 2 & $\mathrm{CV}^{2}$ & Lot 1 & Lot 2 & $\mathrm{CV}^{2}$ \\
\hline $\mathrm{G}(\%)$ & $98^{\mathrm{ns}}$ & 95 & 1.93 & $100^{\mathrm{ns}}$ & 98 & 2.45 \\
\hline $\mathrm{AA}(\%)$ & $95^{\mathrm{ns}}$ & 88 & 6.74 & $98^{*}$ & 91 & 0.61 \\
\hline CT $(\%)$ & $84^{\mathrm{ns}}$ & 79 & 4.60 & $99^{*}$ & 51 & 10.55 \\
\hline EC $\left(\mu\right.$ mhos.cm $\left.\mathrm{cm}^{-1} \cdot \mathrm{g}^{-1}\right)$ & $20.945^{\mathrm{ns}}$ & 21.348 & 4.13 & $17.823^{*}$ & 23.765 & 5.97 \\
\hline SE $(\%)$ & $96^{*}$ & 92 & 1.55 & $98^{\mathrm{ns}}$ & 96 & 2.39 \\
\hline ESI $(\%)$ & $13.85^{*}$ & 12.73 & 3.50 & $15.96^{*}$ & 14.77 & 2.85 \\
\hline
\end{tabular}

*=Significant by $\mathrm{F}$ test, at $5 \%$ of probability; ${ }^{\mathrm{ns}}=$ Non-significant; $\mathrm{CV}^{2}=$ Coefficient of variation; $\mathrm{G}=$ according to Brasil, 2009; $\mathrm{AA}$ and $\mathrm{EC}=$ according to Mondo and Cicero, 2005; CT = according to Dias et al., 2010; $\mathrm{SE}=$ according to Fessel et al., 2000; and ESI = according to Maguire, 1962. 


\section{Data Collection and Analysis}

Plant height, stem diameter, and leaf area index were quantified at phenological stages of four and eight leaves (collar of the leaf visible ), using as reference the treatment that had $100 \%$ of seeds with high vigor, i.e. treatment 1 . For each data collection period, four plants of each vigor level and position within the planting row were used; and the mean values were computed.

Plant height was determined by distance from soil until base of last leaf with visible collar, and the stem diameter was measured at plant base, with aid of a caliper gauge. Leaf area index was obtained by sum of individual leaf areas, calculated by the equation $\mathrm{LA}=0.75 \times \mathrm{L} \times \mathrm{W}$; where ' $\mathrm{L}$ ' is leaf length and 'W' is leaf width (Montgomery, 1911) and divided by the soil area occupied by plant (space between rows multiplied by space between plants within row). All data was submitted to ANOVA (f test, at $5 \%$ probability). In addition, regression analysis was applied for assessing initial growth of plants.

\section{Results and Discussion}

The initial growth of corn crop was assessed by plant height (Figure 1), stem diameter (Figure 2), and leaf area index (Figure 3) at the stages of four and eight leaves, and during the
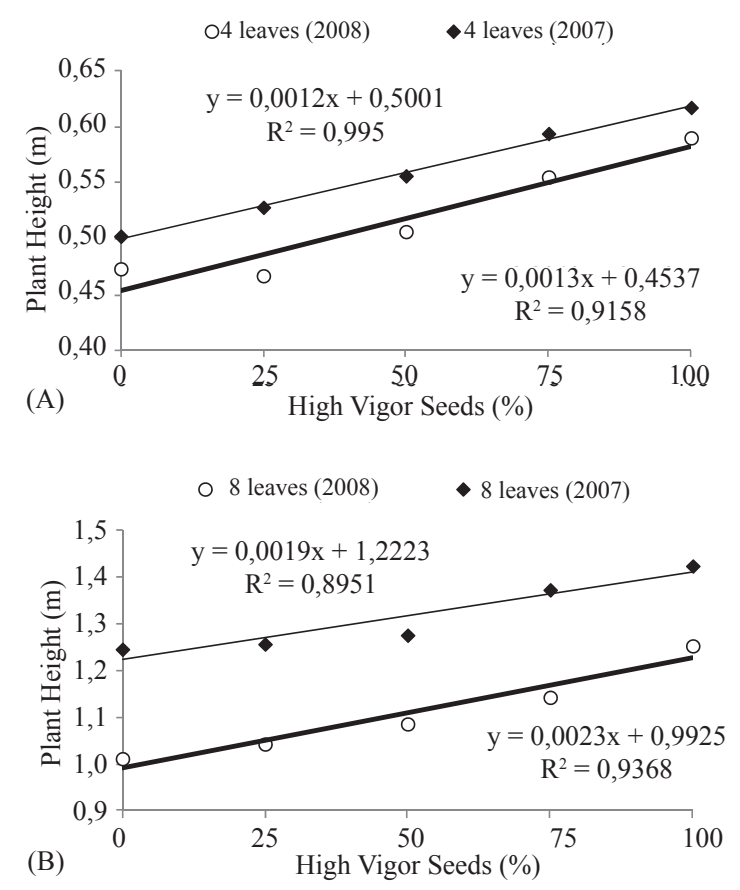

Figure 1. Mean height of corn plants (hybrid Dow 8480); obtained in experiments performed in two different years (2007 and 2008) and measured at the phenological stages of four leaves (A) and eight leaves (B) in a population of plants originated from seeds with different percentages of high vigor seeds. both experimental years. It was observed that for all of these parameters the addition of high vigor seeds within the seeding row resulted in a better development of plant population.

When plant height was assessed, the observed differences in treatments with $100 \%$ seeds of same type (high and low vigor) and assessed at stage of four leaves were around 25\% in both years; and when assessed at stage of eight leaves were $19 \%$ in 2007 and $24 \%$ in 2008 . For plant stem diameter the differences were: $23 \%$ at stage of four leaves and $12 \%$ at stage of eight leaves in 2007; and $37 \%$ at stage of four leaves and $10 \%$ at stage of eight leaves stage in 2008. In a general way, seed vigor would affect crop initial growth; however, those differences should decrease in subsequent development stages, disappearing until the end of crop cycle (Marcos-Filho, 2005). These results agree with results found in this study, once the differences found at stage of four leaves were higher than those found at stage of eight leaves. Besides, for leaf area index results, the higher the percentage of high vigor seeds in the planting row the higher was the crop growth, reaching a maximum increase of $37 \%$ at stage of four leaves, for both years, and $16 \%$ at eight leaves stage, in 2008. By observing results, it is possible to presume that plants originated from low vigor seeds were responsible for reducing crop mean growth.
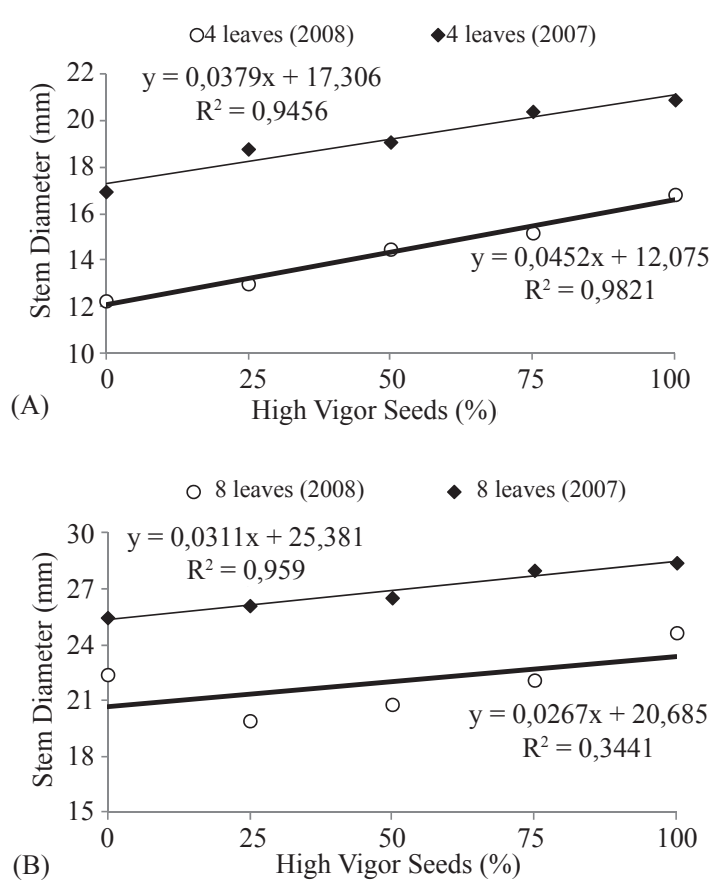

Figure 2. Mean diameter of corn plant stem (hybrid Dow 8480); obtained in experiments performed in two different years (2007 and 2008) and measured at the phenological stages of four leaves (A) and eight leaves (B) in a population of plants originated from seeds with different percentages of high vigor seeds. 

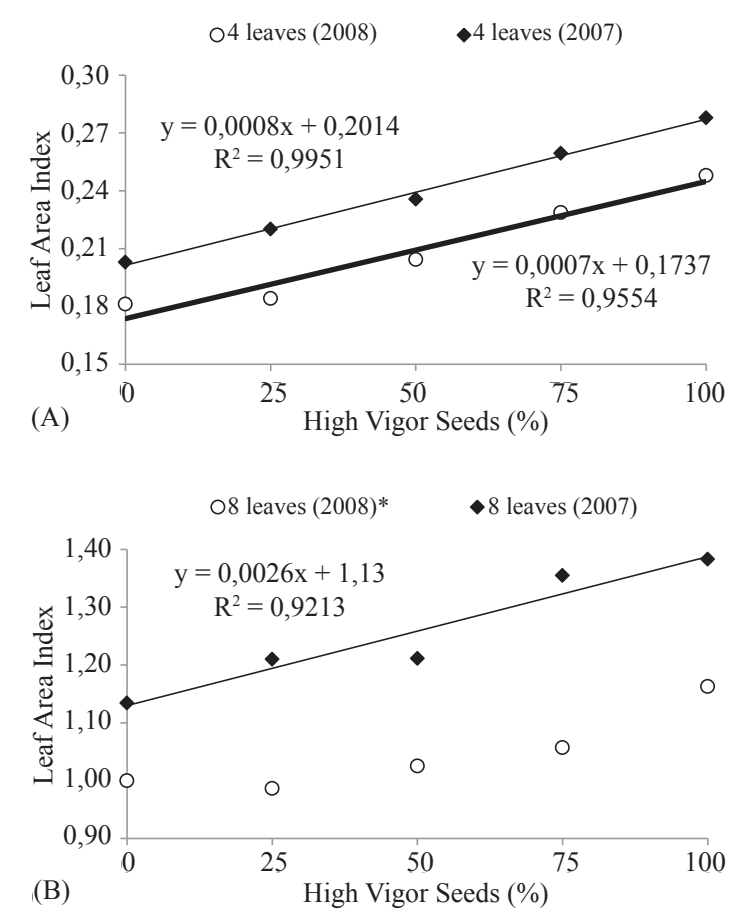

Figure 3. Leaf area index mean of corn plants (hybrid Dow 8480); obtained in experiments performed in two different years (2007 and 2008) and measured at the phenological stages of four leaves (A) and eight leaves (B) in a population of plants originated from seeds with different percentages of high vigor seeds.

*Non-significant by $\mathrm{F}$ test, at $5 \%$ of probability

Considering that grain yield increases were obtained by the efficiency of plants on capturing and using the natural resources, the fast and uniform initial growth of plant population could have caused direct effects on crop grain yields. Pommel et al. (2002) reported that the increases on emergence dates of corn plants, has generated differences in the amount of light received by individual plants; which likewise that photosynthesis of plants is determined by capture and use of solar energy and, once solar light cannot be stored, the competition for this resource is an instantaneous process (Williams et al., 2006). Mondo et al. (2012a), working with corn seeds as well with effects of seed vigor on intra-specific competition, have found that the influence of seed vigor resulted in an unequal growth of plants originated from seeds with high and low vigor, which resulted in a marked intraspecific competition, and in a lower competitive ability for the plants originated from seeds with low vigor, which besides being prevented of growing, were forced to produce less.

Khah et al. (1989), working with wheat plants, have observed that the fast emergence, associated with higher development of seedlings originated from high vigor seeds, resulted on advantages that were sufficient to positively reflect on grain yield as compared to plants originated from low vigor seeds. In addition, Glenn and Daynard (1974) have demonstrated that the irregularity among plants development on population resulted on decreases on grain yield and have suggested that practices aiming at a uniform population development should maximize the population final yield.

In the last decade, several studies analyzed the impact of plant-to-plant variability on maize grain yield at canopy level (Liu et al., 2004a, 2004b; Andrade and Abbate, 2005; Tollenaar et al., 2006), concluding that the non-uniform spatial distribution of plants along the planting row, as well as the uneven seedling emergence, results in variability of biomass of plant-to-plant among adult plants, and also in reduction of grain yield at canopy level. According to Höfs et al. (2004), plants originating from seeds with high physiological potential show higher efficiency on biomass production; these differences, however, should decrease during crop cycle development, but still be measurable at harvest. Egli and Rucker (2012) working with corn seeds under conditions that favor a fast emergence of seedling have found that these conditions would help ensuring an uniform plant stand and that by combining conditions that favor slow emergence with use of low vigor seeds could result in unevenness on the plant stand sufficient to reduce crop yield.

Furthermore, an important point that was identified within this study and that yet needs to be further explored, and about what little has been published, is that greater development of population of plants originated from high vigor seeds can be important components of integrated weed management systems. Based on fact that corn plants have interference on growth and reproduction of weeds, which is a well-known method of weed control, Dias et al. (2010), working with corn seeds have documented that seed vigor have had direct effects on plant initial growth, what was reflected in the competitive capacity of corn plants with weeds, that usually have a lower growth rate than corn.

According to results found in this study, the differences on seed vigor resulted on differences of plant initial growth; what could be compared with differences on growth indexes among compared with varieties or hybrids. Varietal differences in weed suppression ability have already been reported for crops such as corn, potato, cotton and soybean (Callaway, 1990). On a weed competition study, Wicks et al. (1986) have also reported that among 20 varieties of winter-wheat (Triticum aestivum L.), the most weed-suppressive wheat variety allowed a production of weed biomass $82 \%$ lower than the least suppressive variety. Such varietal differences may have resulted from traits conferring capacity for a fast uptake of natural resources, such as high leaf area index and/or extensive roots (Callaway, 1990). 
The selection of genotypes showing morphological and physiological characteristics, such as high height of plants and fast initial growth could increase the plant ability in competing with weeds (Balbinot-Junior and Fleck, 2005). Likewise, adoption of agricultural practices that offer advantages for the plants in competing with weeds could be a viable alternative in reducing, or even on elimination, of use of herbicides. Mondo et al. (2012b) have confirmed that use of high vigor seeds can be an important strategy for the integrated weed management systems, based in the advantages of crop competitive capacity in relation to weeds, what could also help farmers reducing the amounts of herbicides used in their cropping fields.

These approaches relating to high initial growth of population of plants, originated from high vigor seeds, could be identified as a direct result where population of corn plants that originated from high vigor seeds had higher growth. This could increase natural resources uptake and result on grain yield increases; and could so considered as an indirect result. The higher development may also help the corn plants in better competing with weeds as well as helping growers to reduce amounts of herbicide required to control weeds, thus making the corn production more environmentally suitable (Begna et al., 2001).

\section{Conclusion}

The increase on percentage of high vigor seeds in a given seed lot improves the initial growth of corn crop until the stage of eight leaves, mainly on plant height, stem diameter, and leaf area index.

\section{Acknowledgments}

The authors express their appreciation to "CAPES" by the scholarship granted to first author.

\section{References}

ASSOCIATION OF OFFICIAL SEED ANALYSTS [AOSA]. Seed vigor testing handbook. (Contribution, 32): Stillwater, OK, 2002.

ANDRADE, F.H.; ABBATE, P.E. Response of maize and soybean to variability in stand uniformity. Agronomy Journal, v.97, n.4, p.1263-1269, 2005. https://www.agronomy.org/publications/aj/pdfs/97/4/1263

BALBINOT-JUNIOR, A.A.; FLECK, N.G. Weed management in the corn crop through plant spatial arrangement and characteristics of genotypes. Ciência Rural, v.34, n.6, p.245-252, 2005. http://www.scielo.br/pdf/cr/v35n1/a42v35n1.pdf

BEGNA, S.H.; HAMILTON, R.L.; DWYER, L.M.; STEWART, D.W.; CLOUTIER, D. Morphology and yield response to weed pressure by corn hybrids differing in canopy architecture. European Journal of Agronomy, v.14, n.4, p.293302, 2001. http://www.sciencedirect.com/science/article/pii/s1161030101000922
BRASIL. Ministério da Agricultura, Pecuária e Abastecimento. Regras para análise de sementes. Ministério da Agricultura, Pecuária e Abastecimento. Secretária de Defesa Agropecuária. Brasília, DF: MAPA/ACS, 2009. 395p. http://www.agricultura.gov.br/arq_editor/file/laborat $\% \mathrm{c} 3 \% \mathrm{~b} 3$ rio/sementes/ regras $\% 20$ para $\% 20$ analise $\% 20 \mathrm{de} \% 20$ sementes.pdf

CALLAWAY, M.B. Crop varietal tolerance to weeds: a compilation. Department of Plant Breeding and Biometry Publication Series, n.1, Cornell University, Ithaca. 1990.

DIAS, M.A.N.; MONDO, V.H.V.; CICERO, S.M. Maize seed vigor and weed competition. Brazilian Seed Journal, v.32, n.2, p.93-101, 2010. http:// www.scielo.br/pdf/rbs/v32n2/v32n2a11.pdf

DIAS, M.A.N.; PINTO, T.L.F.; MONDO, V.H.V.; CICERO, S.M.; PEDRINI, L.G. Direct effects of soybean seed vigor on weed competition. Brazilian Seed Journal, v.33, n.2, p.346-351, 2011. http://www.scielo.br/pdf/rbs/v33n2/17.pdf

EGLI, D.B.; RUCKER, M. Seed vigor and the uniformity of emergence of corn seedlings. Crop Science, v.52, n.6, p.2774-2782, 2012. https://www. soils.org/publications/cs/pdfs/52/6/2774

FESSEL, S.A.; RODRIGUES, T.J.D.; FAGIOLI, M.; VIEIRA, R.D. Temperature and period of exposure in the accelerated aging test in corn seeds. Brazilian Seed Journal, v.22, n.2, p.163-170, 2000. http://www. abrates.org.br/revista/artigos/2000/v22n2/artigo22.pdf

GLENN, F.B.; DAYNARD, T.B. Effects of genotype planting pattern, and planting density on plant-to-plant variability and grain yield of corn. Canadian Journal of Plant Science,v.54, n.2, p.323-330, 1974.http://pubs. aic.ca/doi/pdf/10.4141/cjps74-050

HAMPTON, J.G. What is seed quality? Seed Science and Technology, v.30, p.1-10, 2002.

HÖFS, A.; SCHUCH, L.O.B.; PESKE, S.T.; BARROS, A.C.S.A. Emergence and initial growth of rice seedlings according to seed vigor. Brazilian Seed Journal, v.26, n.1, p.92-97, 2004. http://www.scielo.br/pdf/\%0d/rbs/v26n1/a14v26n1.pdf

KHAH, E.M.; ROBERTS, E.H.; ELLIS, R.H. Effects of seed ageing on growth and yield of spring wheat at different plant-population densities. Field Crops Research, v.20, n.3, p.175-190, 1989. http://www.sciencedirect.com/ science/article/pii/0378429089900786

KOLCHINSKI, E.M.; SCHUCH, L.O.B.; PESKE, S.T. Seeds vigor and intra-specific competition in soybean. Ciência Rural, v.35, n.6, p.1248-1256, 2005. http://www.scielo.br/pdf/cr/v35n6/a04v35n6.pdf

KOLCHINSKI, E.M.; SCHUCH, L.O.B.; PESKE, S.T. Early growth of soybean plants in relation to seed vigor. Revista Brasileira de Agrociencia, v.12, n.2, p.163-166, 2006. http://www.ufpel.tche.br/faem/agrociencia/v12n2/artigo0.htm

LIU, W.; TOLLENAAR, M.; STEWART, G.; DEEN, W. Within row plant spacing variability does not affect corn yield. Agronomy Journal, v.96, n.1, p.275-280, 2004a. https://www.soils.org/publications/aj/pdfs/96/1/275

LIU, W.; TOLLENAAR, M.; STEWART, G.; DEEN, W. Response of corn grain yield to spatial and temporal variability in emergence. Crop Science, v.44, n.3, p.847-854, 2004b. https://www.crops.org/publications/cs/pdfs/44/3/847

MAGUIRE, J.D. Speed of germination aid in selection and evaluation for seedling emergence and vigor. Crop Science, v.2, n.2, p.176-77, 1962. https:// www.crops.org/publications/cs/abstracts/2/2/cs0020020176

MARCOS-FILHO, J. Fisiologia de sementes de plantas cultivadas. Piracicaba: Fealq, 2005. 495p.

MELO, P.T.B.S.; SCHUCH, L.O.B.; ASSIS, F.N.; CONCENÇO, G. 
Individual behavior of rice plants from different physiological quality seeds in rice populations. Brazilian Seed Journal, v.28, n.2, p.84-94, 2006. http:// www.scielo.br/pdf/rbs/v28n2/a11v28n2.pdf

MIELEZRSKI, F.; SCHUCH, L.O.B.; PESKE, S.T.; PANOZZO, L.E.; PESKE, F.B.; CARVALHO, R.R. Field performance of isolated plants of hybrid rice in function of the seed physiological quality. Brazilian Seed Journal, v.30, n.3, p.86-94, 2008. http://www.scielo.br/pdf/rbs/v30n3/18.pdf

MONDO, V.H.V.; CICERO, S.M. Using image analysis to evaluate the quality of maize seeds located in different positions on the ear. Brazilian Seed Journal, v.27, n.1, p.9-18, 2005. http://www.scielo.br/pdf/rbs/v27n1/25176.pdf

MONDO, V.H.V.; CICERO, S.M.; DOURADO-NETO, D.; PUPIM, T.L.; DIAS, M.A.N. Maize seed vigor and plant performance. Brazilian Seed Journal, v.34, n.1, p.143-155, 2012a. http://www.scielo.br/pdf/rbs/v34n1/a18v34n1.pdf

MONDO, V.H.V.; CICERO, S.M.; DIAS, M.A.N. Vigor de sementes e a matocompetição. Informativo Abrates, v.22, n.1, p.30-34, 2012b. http://www. abrates.org.br/portal/images/stories/informativos/v22n1/artigo_10.pdf

MONTGOMERY, E.G. Correlation studies in corn. Nebraska Agricultural Experiment Station Annual report, v.24, p.108-159, 1911.

POMMEL, B.; MOURAUX, D.; CAPPELLEN, O.; LEDENT, J.F. Influence of delayed emergence and canopy skips on the growth and development of maize plants: A plant scale approach with CERES-Maize. European Journal of Agronomy, v.16, n.4, p.263-277, 2002. http://www.sciencedirect.com/ science/article/pii/s1161030101001307

RAJCAN, I.; SWANTON, C.J. Understanding maize-weed competition: resource competition, light quality and the whole plant. Field Crops Research, v.71, n.2, p.139-150, 2001. http://www.sciencedirect.com/science/article/pii/ s0378429001001599
SCHUCH, L.O.B.; NEDEL, J.L.; ASSIS, F.N.; MAIA, M.S. Seed vigor and growth analysis of black oats. Scientia Agricola, v.57, n.2, p.305-312, 2000. http://www.scielo.br/pdf/sa/v57n2/v57n2a18.pdf

SCHUCH, L.O.B.; KOLCHINSKI, E.M.; FINATTO, J.A. Seed physiological quality and individual plants performance in soybean. Brazilian Seed Journal, v.31, n.1, p.144-149, 2009. http://www.scielo.br/pdf/rbs/v31n1/a16v31n1.pdf

TOLLENAAR, M.; DEEN, W.; ECHART, L.; LIU, W. Effect of crowding stress on dry matter accumulation and harvest index. Agronomy Journal, v.98, n.4, p.930-937, 2006. https://www.agronomy.org/publications/aj/pdfs/98/4/930

VANZOLINI, S.; CARVALHO, N.M. Effects of soybean seed vigor on field plant performance. Brazilian Seed Journal, v.24, n.1, p.33-41, 2002. http:// www.scielo.br/pdf/rbs/v24n1/v24n1a06.pdf

WICKS, G.A.; RAMSEL, R.E.; NORDQUIST, P.T.; SCHMIDT, J. W.; CHALLAIAH. Impact of wheat cultivars on establishment and suppression of summer annual weeds. Agronomy Journal, v.78, n.1, p.59-62, 1986. https://www.crops.org/publications/aj/abstracts/78/1/aj0780010059

WILLIAMS, M.M. II.; BOYDSTON, R.A.; DAVIS, A.S. Canopy variation among three sweet corn hybrids and implications for light competition. HortScience, v.41, n.6, p.1449-1454, 2006. http://hortsci.ashspublications. org/content/41/6/1449.full.pdf + html 